\title{
CORRIGENDUM
}

\section{Early improvement in food cravings are associated with long-term weight loss success in a large clinical sample}

M Dalton, G Finlayson, B Walsh, AE Halseth, C Duarte and JE Blundell

International Journal of Obesity (2018) 42, 119; doi:10.1038/ijo.2017.238

Correction to: International Journal of Obesity (2017) 41, 1232-1236; doi:10.1038/ijo.2017.89

Since publication the authors of this paper have requested that it be made open access under the CC BY licence.

\section{article} article are included in the article's Creative Commons license, unless indicated otherwis in the credit line; if the material is not included under the Creative Commons license, users will need to obtain permission from the license holder to reproduce the material. To view a copy of this license, visit http://creativecommons.org/licenses/by/4.0/

(๑) The Author(s) 2018 